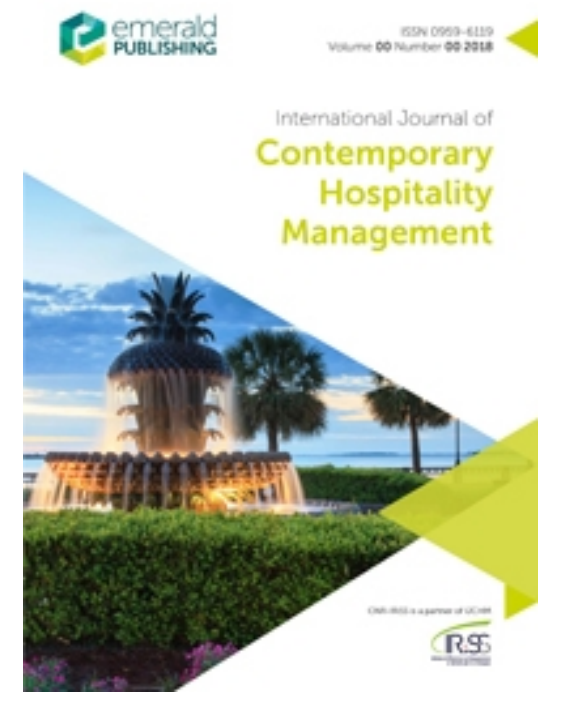

\title{
Customer experience and brand loyalty in the full-service hotel sector: The role of brand affect
}

\begin{tabular}{|r|l|}
\hline Journal: & International Journal of Contemporary Hospitality Management \\
\hline Manuscript ID & IJCHM-10-2020-1177.R2 \\
\hline Manuscript Type: & Original Article \\
\hline Keywords: & $\begin{array}{l}\text { Customer experience, Brand Loyalty, Brand trust, Brand affect, Brand } \\
\text { involvement }\end{array}$ \\
\hline
\end{tabular}

\section{SCHOLARONE ${ }^{\mathrm{m}}$ \\ Manuscripts}




\title{
Customer experience and brand loyalty in the full-service hotel sector: The role of brand affect
}

\begin{abstract}
Purpose-This study proposed a comprehensive causal model to examine the relationships between customer experience and four key factors in brand building, i.e., brand loyalty, brand trust, brand affect, and brand involvement. The dimensionality of customer experience in fullservice hotel is also particularly examined in relation to brand building.

Design/methodology/approach- Three steps of data collection were employed: interviews of 50 customers on their experiences of staying full-service hotels, a small survey of 176 hotel guests to establish the measurement scale of customer experience and a major survey of 732 hotel customers in 10 major Chinese cities to test the model of brand loyalty.

Findings- Customers' experiences with full-service hotels is proposed to be categorised into functional, affective and social. There is a chain effect from customer experience to brand trust and to brand affect, and then to brand loyalty. The brand involvement does moderate relationships between customer experience and brand trust, and brand affect, but not brand loyalty.
\end{abstract}

Practical implications- For full-service hotels, social and functional experiences are critical in building brand loyalty and therefore they need to be the focal points in the enhancement of customer experience. Also hoteliers are advised to develop emotional connections between the customers and the hotel brand - effective way of building trust and affection.

Originality/value- This paper is one of the first few studies to link customer experience to brand loyalty with comprehensive causal effect analysis. The study also contributes to the knowledge of customer experience in the context of the full-service hotel sector.

Keywords Customer experience, Brand loyalty, Brand trust, Brand affect, Brand involvement Paper type Research paper 


\section{Introduction}

The hotel industry is highly experience-oriented. Merely offering commodities, goods, and services are no longer sufficient for hotels to sustain long-term profitability, as they have to bundle their services with enhanced experiences for the customers (Cetin and Dincer, 2014). Experiences can create a unique value and memorable time for customers (Ali et al., 2014). It will strongly affect customers' satisfaction, image, perceived value, loyalty, and thereby their recommendation and purchasing behaviors (Cetin and Dincer, 2014; Bravo et al., 2019; Hussein et al., 2018).

Due to the importance of customer experience, several studies have attempted to define the term of experience and explored its dimensionality, making great contributions to the knowledge of customer experience. Yet, some dimensionalities of customer experience were developed without distinguishing the type of hotels, e.g., full-service, no-frill, or boutique (Alnawas and Hemsley-Brown, 2019; Hemmington, 2007; Knutson et al., 2009; Walls, 2013;). The full-service type offers the usual luxurious amenities and facilities with a high staffing ratio to support these services (Kim-Soon et al., 2014). Their customers acquire experiences not only through enjoying those facilities available in their rooms, but also when using auxiliary facilities such as fitness centers or swimming pool (Yoon and Lee, 2017), as well as other personalized services. Hence, a specific study of customer experience in the full-service hotel sub-sector can enhance our understanding of how customer experience plays a role in hotel management and brand building.

Customer experience is an essential part of a successful hotel brand ( $\mathrm{Xu}$ and $\mathrm{Chan}, 2010)$. The brand strategy of hotels should be highly customer-oriented as asserted by Prasad and Dev 
(2000). By creating cohesive, authentic, and sensory-stimulating customer experiences, hotels can connect with the customer's affective faculties, and further secure their brand preference and loyalty (Berry and Carbone, 2007). From the perspective of competition, the experience offered by a hotel, unlike physical environments, cannot be imitated easily by rivals, and therefore can be used to create the uniqueness of a hotel brand (Iglesias et al., 2011; Wang et al., 2020). However, experiential aspects of hotel brand building have been largely overlooked in the literature (So and King, 2010). Only a handful of studies empirically explored the role of customer experience in hotel brand building (e.g., Hosseini et al., 2015; Hosseini and Zainal, 2016; Shobri et al., 2015). Most of these studies employed a qualitative approach (e.g., Harkison et al., 2018; Walls et al., 2011).

To examine the linkages of customer experience and brand building in full-service hotels, this study aims to answer: how does customer experience affect brand loyalty in the hotel sector? First, dimensions underlining customer experience in full-service hotels are explored using both qualitative and quantitative approaches. Then, a comprehensive model is constructed, including the following key factors: customers (using the construct of customer experience), affect of brand (using the constructs of brand involvement and brand affect), cognition of brand (using the construct of brand trust), and conation and behavior of brand (using the construct of brand loyalty). By examining the aforementioned model, this study establishes the relationship between customer experience and brand loyalty, which has been theoretically discussed in a limited studies of full-service hotels but yet to be supported in any empirical study.

In addition, studying this phenomenon in the context of mainland China is on the basis of the rapid development of full-service hotels in the country and growth of the outbound travel 
market. By January 1, 2020, the total number of accommodation facilities in China is 608 thousands with 18.9 million guest rooms (China Hotel Association, 2020). However, 90\% of the hotels in China currently do not have a recognizable brand yet (Wang, 2020). In the next 10 to 20 years, the main tasks for China's hotel industry will be brand development and rebranding (Ren et al., 2016). In addition, Chinese tourists have been the world's largest spenders over the past few years (UNWTO, 2019), with an increasing amount of outbound travel (CMCT, 2020). Thereby, the study of Chinese customers' experience and its relationship with brand building can enlighten the managerial practices for both domestic and international fullservice hotel managers targeting Chinese customers and attempting to offer better customer experience.

\section{Literature review and proposed theoretical model}

Customer Experience in Experience-based Economy

As the key concept in the experience-based economy, customer experience is one of the most controversial topics in hospitality area in the last decade (Ali et al., 2019; Altinay and Taheri, 2019). Schmitt (1999) defined customer experience as an internal feeling of an individual aroused by external stimuli. The classical measures of customer experience include entertainment, education, escape, and aestheticism (Pine and Gilmore, 1998); sense, feel, think, act, and relate (Schmitt, 1999); and functional and emotional clues (Berry et al., 2006).

According to Walls (2011), the construct, customer experience, has four components: perceived physical experience elements, perceived human interaction elements, individual characteristics, and situational factors. Specifically, the first two components, which are 
regarded as the most critical elements, have been confirmed by several studies (e.g., Cetin and Walls, 2016; Hussein et al., 2018; Ren et al., 2016; Walls, 2013). Later, a new structure of customer experience including two composites of affective and intellectual experience was proposed by Foroudi et al. (2016) to reflect trends in the digital era. Pertaining to luxury accommodation experience, Harkison et al. (2018) argued that the key elements should include ethos and unique selling points, physical and human interaction experience elements and cocreation with the customers. However, most of the aforementioned constructs do not fully reflect the social settings and customers' requirements of a full-service hotel. In the context of China, for example, face-enhancing function, which was hardly mentioned in previous studies of hotel customer's experience, may significantly influence East Asian's perceptions on luxurious products (Monkhouse et al., 2012). It is reasonable to speculate that face consciousness is a part of Chinese customer's experience when they stay in full-service hotels. In summary, customer experience in the full-service hotel sector is a multi-dimensional construct. These different types of customer experience could be classified into three main dimensions, i.e., functional, affective, and social. Functional experience refers to products or services provided by a hotel that satisfies customer's functional needs. Affective experience refers to customer's emotional responses. Social experience highlights customer's needs related to obtaining social status and gaining social legitimacy. Later, the Methodology Section elaborates on the development of measurement scale for customer experience in the full-service hotel sector in order to identify respective measurement items for its three dimensions.

\section{Brand loyalty}


Brand loyalty is employed in this study as the outcome variable in the customer-brand relationship building. The importance of brand loyalty has been widely recognized in the hotel industry over many decades (Rather and Sharma, 2016; So et al., 2013). It is an outcome of the interaction between a customer's attitude and a hotel brand, which stimulates repeated purchase of that brand (Dick and Basu, 1994). A sizeable literature investigated brand loyalty per se and its related factors in the hotel industry (e.g., Back and Parks, 2003; Tepeci, 1999; Wilkins et al., 2009). These studies tested a range of antecedents of brand loyalty, such as brand experience (Ong et al., 2018), brand identification (So et al., 2013), brand satisfaction, brand commitment (Rather and Sharma, 2016), brand passion, brand affection and self-brand connection (Hemsley-Brown and Alnawas, 2016), brand attachment (Bahri-Ammari et al., 2016), co-branding (Kim et al., 2007); and customer satisfaction (Al-Msallam, 2015), customer engagement (So et al., 2016), C2C interactions (Luo et al., 2019), product involvement (Hochgraefe et al., 2012), and service quality (Malik et al., 2012). However, the formation process of brand loyalty is complicated, and thereby calls upon further exploration.

\section{The Critical Role of Customer Experience in Hotel Brand Building}

Back and Parks (2003) proposed that customer satisfaction is linked to brand loyalty. They categories brand loyalty into attitudinal (comprises of cognitive, affective and conative aspects) and behavioral (defined as a customer's overt behavior toward a specific brand, leading to repeated purchasing pattern). In examining the chain effects among these different types of brand loyalty, Back and Parks (2003) argue that customer satisfaction influences the formation of attitudinal, and then behavioral brand loyalty. However, unlike Back and Parks (2003), this study argues that customer experience, instead of its proxy - customer satisfaction, is a more 
direct measurement reflecting the new era of the experience-based economy (Jain et al., 2017; Pine and Gilmore, 1998). Management of customer experience is critical for building brand loyalty (Mascarenhas et al., 2004; Woodside and Walser, 2007). Positive experience can constitute a differentiation feature, inducing customer preference over other brands and thereby establishing their brand loyalty (Mascarenhas et al., 2004; Iglesias et al., 2011), whereas negative experience could lead to the termination of a purchasing decision (EI Naggar and Bendary, 2017). Hence, it is important to create a direct interaction between customers and the brand to generate a positive customer experience (Biedenbach and Marell, 2010). Mascarenhas et al. (2006) assert that developing customer experience could be extraordinarily valuable in terms of creating customer's loyalty.

\section{Brand trust}

Brand trust can be defined as customers' feelings of security when they interact with a brand, since they believe that the brand is reliable and will responsibly uphold their interest and welfare (Delgado-Ballester et al., 2003). The customer's experience of products or services is the most relevant and important source of information that can be used to evaluate the brand (Huang, 2017; Swaminathan et al., 2001). If a brand delivers its promised performance over time, customers would feel more secure (Ashley and Leonard, 2009) and have greater confidence in the brand (Sunyansanoa et al., 2013). Hence, brand trust results from customers' previous experiences and prior interactions with brands (Agustin and Singh, 2005). Although it has not yet been widely investigated in hospitality research, the positive relationship between customer experience and brand trust has been empirically supported by several studies in 
broader marketing literature (e.g., EI Naggar and Bendary, 2017; Maghzi et al., 2011; Kang et al., 2017; Song et al., 2012; Valenzuela and Vásquez-Párraga, 2006).

\section{Brand affect}

One of the associations between a customer and a brand could be brand affect. By definition, brand affect reflects both a customer's positive and negative feelings towards a brand (Soedarto et al., 2019). To fit the context in China, He (2008) proposed a measurement of brand affect with two dimensions. One is "True feelings". Feelings, such as attraction, pleasure, excitement, and happiness belong to this category. The other one is "Due feelings". This is rooted in social interactions and ethical norms, such as etiquette, occasion, patriotism, collectivism. Customers' positive experience can elicit a positive emotional response (Song et al., 2012). When interacting with a brand, experience is one of the most important sources for consumers to know the brand (Chaudhuri, 1997). In the process of this experience, consumers interact with and react to the brand. This kind of reaction starts from the sensory level of consumers and extends to the emotional sphere. Once this kind of emotion is generated, it stimulates consumers' desire to purchase, followed by the subsequent behavior of purchasing ( $\mathrm{Su}$ et al., 2018) and thereby behavioral loyalty (Bahri-Ammari et al., 2016). Therefore, a highly pleasant experience is likely to evoke brand affect (Matzler et al., 2006).

Thereby, the following hypotheses are proposed:

$\mathrm{H}_{1}$ : Customer experience has a positive impact on hotel brand loyalty.

$\mathrm{H}_{2}$ : Customer experience has a positive impact on hotel brand trust. 
$\mathrm{H}_{3}$ : Customer experience has a positive impact on hotel brand affect.

\section{The mediating effects of brand trust and brand affect}

Brand trust and brand affect are two constructs investigated simultaneously in several studies. Matzler et al. (2008) investigated the mediating role of brand trust and brand affect between risk aversion and brand loyalty. The chain effect, from brand affect and brand trust to brand loyalty and then to market share and relative price, was examined by Chaudhuri and Holbrook (2001). Another chain effect, from brand image, trust and affect to brand loyalty, and then to consumer brand extension attitude, was also tested by Anwar et al. (2011). In luxury brand management, brand trust and affect are critical to the building of the customer-brand relationship (Song et al., 2012). The inclusion of brand trust and affect into one model offers a more sophisticated understanding of brand building, and both cognitive and affective pathways are inspected.

In above studies, brand trust is verified to be an important antecedent variable of brand affect (Gecti and Zengin, 2013). Brand trust can be treated as a process that occurs when customers think and consider their long-term experience of the brand, while brand affect is an impulsive feeling towards a brand (Chaudhuri and Holbrook, 2001). To be a cognitive component (Casalo et al., 2007), brand trust precedes the emotional response, namely brand affect.

Brand trust is considered as an important factor in building brand loyalty (Delgado-Ballester et al., 2003). The causal relationship between brand trust and brand loyalty was examined in the context of the cable TV industry (Oyedeji and Hou, 2010), banking services (Ndubisi et al., 
2007) and mobile phone service (El Naggar and Bendar, 2017). Moreover, customers' brand experience (Kang et al., 2017) was confirmed to be related to brand loyalty with a mediating effect of brand trust. However, in work of Huang (2017), brand trust was not a significant mediator between experience and loyalty. Trust could also be a resultant of customer-brand identification (Shin et al., 2020). Therefore, the role of brand trust between customer experience and brand loyalty needs to be specifically tested in the context of full-service hotel.

Brand affect is a strong driver of brand loyalty (Gecti and Zengin, 2013; Kabadayi and Alan, 2012). Iglesias et al. (2011) suggested that customers' superior experiences may enhance their emotional responses to the brand. Then, the emotions, such as happy, joyful, or affectionate, elicited by the brand can prompt greater purchase and attitudinal loyalty (Matzler et al., 2008). A long-term affective attachment between a brand and the customer can provide steady benefits to customers (Gundlach et al., 1995) and lead to greater commitment in the brand, i.e., loyalty (Chaudhuri and Holbrook, 2001). The relationship between brand affect and brand loyalty has been empirically proved by works of Anwar et al. (2011), Chaudhuri and Holbrook (2001), and Kabadayi and Alan (2012).

Thereby, the following hypotheses were proposed:

$\mathrm{H}_{4}$ : Hotel brand trust mediates the relationship between customer experience and brand loyalty. $\mathrm{H}_{5}$ : Hotel brand affect mediates the relationship between customer experience and brand loyalty.

$\mathrm{H}_{6}$ : Hotel brand trust mediates the relationship between customer experience and brand affect. 


\section{Moderation effect of brand involvement}

In the context of consumption, involvement has been defined as “a person's perceived relevance of the object based on inherent needs, values, and interests" (Zaichkowsky, 1985, p. 342). It has two categories: product and brand involvement (Zaichkowsky, 1985). Under the conditions of similar features and quality, consumers would choose a product based on their familiarity with the brand (Kim and Sung, 2009). Compared to product involvement, brand involvement has received much less attention in research. Several attempts in the broader area of management include Dahlgren (2011), Lockshin et al. (1997), Shiue and Li (2013) and, most recently, Bian and Haque (2020). However, for the full-service hotel sector, the role of customer's brand involvement in brand building has rarely been discussed. The gap of knowledge remains.

Brand involvement is closely related to customer experience. Gentile et al. (2007, p. 397) suggested that "customer experience ... is strictly personal and implies the customer's involvement at different levels (rational, emotional, sensorial, physical, and spiritual)". Yang and Chan (2010) verified in an empirical study that the higher involvement of customers in the hotel, the higher the quality of customer experience, and vice-versa. Involvement is also a predictor for brand loyalty, as suggested by Knox and Walker (2003) and Vazifehdoost et al. (2014). Further, the effect of brand trust can fluctuate with different levels of customer involvement (Delgado-Ballester and Munuera-Alemán, 2001). Brand involvement is also verified as an important moderate variable in the customer-brand relationship in various settings (e.g., Kim et al., 2012; Suh and Youjae, 2006; Swoboda et al., 2009). Customers with 
higher brand involvement might have closer ties with brands and thereby positive attitude and affect towards the hotel brands.

Thereby, this study proposes:

$\mathrm{H}_{7 \mathrm{a}}$ : The relationship between customer experience and brand trust is positively moderated by brand involvement.

$\mathrm{H}_{7 \mathrm{~b}}$ : The relationship between customer experience and brand affect is positively moderated by brand involvement.

$\mathrm{H}_{7 \mathrm{c}}$ : The relationship between customer experience and brand loyalty is positively moderated by brand involvement.

Model of chain effects between hotel customer experience and brand loyalty

The conceptual model proposed in this study attempts to establish (i) the linkage between the customer experience dimensions and brand loyalty, (ii) the mediate roles of brand trust and brand affect and (iii) the moderate role of brand involvement on the relationships between customer experience and brand trust, brand affect, and brand loyalty. Overall, the proposed model captures the key constructs that explain how the customer's experience impacts brand loyalty as in Figure 1.

Please Insert Figure 1 Here

Methodology

Development of measurement items for customer experience 
The dimensionality of customer experience was specifically explored for full-service hotels. A total of 50 customers staying in full-service hotels located in Beijing, Shanghai, Shenzhen, Hangzhou and Zhengzhou, China, were interviewed from March to April 2018. Two fullservice hotels from each city and five customers from each hotel were selected. Questions asked were principally related to the customer's experience in the hotel and the factors influencing their experience. The average interview time for each customer was approximately 30 minutes. The collected data were analyzed by one of the authors and research assistants. The process of coding follows steps suggested by Richards (2009). Finally, 28 items (details are available in the Online Supplementary Document) were extracted to be used for further analysis.

Then, in July 2018, a small survey was conducted. Two hundred customers from full-service hotels in ten cities of China, i.e., Shanghai, Beijing, Shenzhen, Chengdu, Zhengzhou, Qingdao, Hangzhou, Guangzhou, Xiamen and Nanjing, were asked to complete a questionnaire related to their customer experience. A total of 176 valid responses were collected. The data were randomly divided into two parts. One was used to refine the items, and the other half was used to examine the validity and reliability. Three methods were used to purify the initial items. First, the corrected item total correlation (CITC) was used. Items lower than 0.3 were deleted. Second, items with Cronbach's $\alpha$ values lower than 0.6 were also eliminated. After the first two steps, merely 15 out of 28 items remained. Then, exploratory factor analysis (EFA) was used to reduce the dimensions. The KMO and Bartlett examination equal to 0.863 and 9871.066 respectively. Using the principal component analysis and maximum variance orthogonal rotation method, three dimensions were extracted with the standard of eigenvalue value greater 
than 1 (Table 1). The cumulative variance of the three dimensions is explained as $73.69 \%$. The Cronbach' $\alpha$ for the entire measure is 0.877 . By the analysis of confirmatory factor analysis (CFA), the factor loading for each item is higher than 0.7 . That means each item converges to its latent variable, and the scale has convergent validity. All average variation extraction (AVE) values are greater than 0.5 , and also greater than the correlation coefficient between factors. The discriminant validity is, therefore, ensured (Wu, 2009).

\section{Please Insert Table 1 Here}

In summary, the measurement items identified for customer experience are categorised into functional, affective and social dimensions. The functional experience as expected is related to products or services such as the facilities, environment and atmosphere, staff's service attitude and skills. The affective experience reflects on the customers' emotional responses, either positive or negative. However, the empirical analysis indicated that customers generally have positive emotional responses to the full-service hotel (see Online Supplementary Document). Items for both functional and affective dimensions do not diverge far from the literature. The novel items for social experience highlighting customers' social needs are related to social belonging, respect, self-esteem, and social self-image. This scale development study has identified 15 items as in Table 1, with the details of the items are available in the Online Supplementary Document).

Generating measurement items through literature 
The measurements of brand trust, brand affect, brand loyalty and brand involvement were obtained from previous studies, including He (2008); Oliver (1999); Wang \& Zhou (2011); Yuan et al., (2007); Zaichkowsky (1985) ; and Zeithmal et al., (1996). The entire scales and respective citations are available in the Online Supplementary Document. All above mentioned scales were defined as multi-dimensional constructs. Three experts were invited to go through the whole questionnaire, in order to ensure content validity. All items were measured by a 7point Likert scale, where 1 represents strongly disagree, while 7 represents strongly agree.

\section{Data collection}

The major survey was conducted in ten of China's main cities, similar to those in the first round of sampling as above. The selection was based on two considerations. First, these cities are China's main tourist destinations attracting a high number of visitors, either travelling for pleasure or business. Second, a vast variety of hotel brands can be found in these cities, and competition is very intense. Therefore, branding is critical for hotels in these cities. Two fullservice hotels per city were selected. The selected hotels are chain hotels of both international and domestic brands.

During the period from October 2018 to March 2019, target sample of customers were approached by a systematic sampling method at the main entrance of hotel lobbies. Every fifth customer leaving the hotel was invited to complete the questionnaire, following the suggestion of Heung and Lam (2003). Full service hotels with different brands were chosen from a hotel list provided by each city's hotels association. In each hotel, one or two pre-trained survey helpers selected and interviewed respondents intentionally to ensure the diversity of samples. 
Different genders, age, incomes and educations were covered (Table 2). Out of 1000 respondents, 732 of them are valid responses. The large sample size enhances the representativeness of the sample, and is suitable for the structural equation modeling (SEM), as partial least squares (PLS)-SEM analysis expects a ratio of 10 responses for each item in the analysis (Iacobucci, 2010).

Please Insert Table 2 Here

\section{Data Analysis}

The data analysis includes four steps. First, the descriptive statistics and EFA were performed using SPSS 19. Second the measurement model was tested using the PLS-SEM approach by Smartpls 3. The examination of measurement model generates the reliability, convergent, and discriminant validity for constructs. Third, a structural model examining causal relationships between different dimensions of customer experience and brand loyalty were estimated with Smartpls 3. Fourth, to test the aforesaid hypotheses 1-7, the structural model including all latent variables was computed. The PLS-SEM approach is used. It can analyze causal relationships, as well as mediate and moderate effects simultaneously with a loose requirement of normal distribution of data (Urbach and Ahlemann, 2010). As a large number of items $(n=49)$ were used to measure the latent variables, item parceling strategy was employed to reduce the number of items and the total measurement error, according to the suggestion of Bandalos (2002).

\section{Findings}




\section{Reliability and validity}

Respondents generally hold a positive attitude towards their hotel experience and hotel brand, since the mean scores of all items are above 5. Items with factor loading in EFA lower than 0.5 were eliminated from subsequent analysis. The factor loadings for all items in CFA are higher than 0.8. The Cronbach' $\alpha$ and Dillon-Goldstein's rho coefficients are greater than 0.70 for all constructs supporting the reliability of measurement tools (Hair et al, 2014). The composite reliability of each construct reaches the acceptable standard of 0.7 (Urbach and Ahlemann, 2010). AVE for each construct are higher than 0.5 indicating the convergent validity (Alsharo, 2016). The cross-loadings automatically calculated by Smartpls are checked to ensure the discriminant validity. Table 3 shows the calculation of reliability and validity indicators.

\section{Please Insert Table 3 Here}

\section{The effects of customer experience dimensionality on brand loyalty}

The causal relations between three dimensions of customer experience (i.e., functional experience, affective experience, and social experience) and brand loyalty were examined to investigate whether different facets of customer experience have similar influences on brand loyalty. The PLS-SEM approach was utilized, as the dependent variable brand loyalty has two dimensions (i.e., attitudinal and behavioral). The $\mathrm{R}^{2}$ of the model indicates that affective, functional and social experience explain $58.1 \%$ of the variance in brand loyalty, suggesting the homological validity of the model as recommended by Chin (1988). The value of StoneGeisser $\mathrm{Q}^{2}$, calculated using the blindfolding procedure, is found to be greater than zero $\left(\mathrm{Q}^{2}\right.$ $=0.512$ ), supporting a predictive relevance in explaining the endogenous latent variable (Urbach and Ahlemann, 2010). Standardized Root Mean Square Residual (SRMR) equals to 
$0.048(<0.5)$ suggesting that the goodness of fit is satisfactory (Wen et al., 2004). The values of variance inflation factor (VIF) are less than the required threshold of 5 (Hair et al., 2011), therefore a multicollinearity issue does not exist. The path coefficients of functional experience, social experience, and affective experience on brand loyalty are $0.256,0.529$ and 0.045 respectively. The social experience is the most significant determiner of brand loyalty (Table 4). For full-service hotels, customers can generate brand loyalty because of satisfaction with their functional experience. But social experience has a more significant relation with brand loyalty. Customers' feelings of respect, social interaction, social self-image, and self-esteem gained from their experiences staying in a full-service hotel is more critical in the formation of their loyalty to the brand. It worth to note that in this study, the respondents, in general, expressed a very good customer experience (Means=5.80), suggesting that they tend to form positive attitudes and possibly inducing positive bias towards brand loyalty.

\section{Please Insert Table 4 Here}

\section{Test of the structural model}

The structural model including comprehensive causal effects from customer experience to brand trust and brand affect, and then to brand loyalty is tested. Item parceling can reduce model parameters and generate more stable parameter estimates, greater reliability and more definitive rotational results (Bandalos, 2002). It is appropriate to be used when items are merely tools for building a measurement model and relations among latent variables are focused (Little et al., 2002). The internal-consistency approach of item parceling was used in this study. Items of each sub-dimension (Figure 1), which are unidimensional theoretically and loaded on one 
dimension in EFA, were averaged and replaced with the new mean score. Consequently, customer experience are examined by three observed items (Functional, social and affective experience); brand trust is also examined by three observed items (quality, capability and benevolence trust); brand affect is examined by two observed items (Due and true affect); and brand loyalty is examined by two observed items (attitudinal and behavioral loyalty). As shown in Table 5, the path coefficients from customer experience to brand trust, brand affect and brand loyalty are $0.619,0.237$ and -0.011 . The $p$ values for the first two paths are lower than 0.001. Therefore, customer experience significantly relates to brand trust and brand affect. There is no direct relationship between customer experience and brand loyalty. Tests of brand trust and brand affect's mediation effects indicate that brand affect is a mediator between customer experience and brand loyalty. Brand trust only has the mediate influence through the chain effect from brand affect to brand loyalty. Since customer experience does not have a direct effect to brand loyalty, brand trust and brand affect are the full mediators between customer experience and brand loyalty. To sum up, the hypotheses H2, H3, H5, and H6 are confirmed in this analysis.

\section{Please Insert Table 5 Here}

Brand involvement has a moderating effect on the relationships between customer experience and brand trust; and customer experience and brand affect. But brand involvement does not moderate the relationship between customer experience and brand loyalty. $\mathrm{H} 7 \mathrm{a}$, and $\mathrm{H} 7 \mathrm{~b}$ are verified. The $\mathrm{R}^{2}$ of the model indicates that all predictive variables explain $81.5 \%$ of the variance in brand loyalty (Chin, 1988). The value of Stone-Geisser $\mathrm{Q}^{2}$ is greater than zero $\left(\mathrm{Q}^{2}\right.$ 
$=0.717$ ). The predictive relevance explains the endogenous latent variable (Urbach and Ahlemann, 2010). SRMR equals to 0.047 which is lower than 0.08 indicating a good model fit (Wen et al., 2004).

\section{Conclusions}

\section{Discussion and conclusions}

Three major conclusions are proposed. Firstly, this study put forward that customer experience consists of three dimensions: functional, affective and social experience. The scope of functional experience, mainly relating to products and services offered by hotels, is consistent with findings of many previous studies, which include: physical experience (Hussein et al., 2018; Ying et al., 2020), physical environment (Walls, 2013), functional and mechanical experience (Chepngetich et al., 2019), tangible-sensorial experience (Ren et al., 2016), and perceived physical experience (Walls et al., 2011). Affective experience, rarely discussed in prior literature, is identified in this study, echoing the suggestion of Walls et al. (2011) and Wu and Gao (2019) to emphasize the emotional experience of customers rather than purely cognitive experiences.

The concept of social experience, proposed in this study, is related to but beyond human interaction (Lin et al., 2020; Walls, 2013), staff relational / interactional experience (Ren et al., 2016) and humanity clues (Chepngetich et al., 2019) as stated in prior studies. It shall include customer's self-esteem and social self-image, which rarely mentioned in other studies. The full-service hotel is normally a high-end, luxury hotel. Staying in a full-service hotel, customers are not only looking for superior services, but also meant to impress, to "enhance face" in front 
of other people, which is a widespread phenomenon rooted in Chinese culture (Mattila, 1999).

Compared to the other two types, social experience is more critical in building brand loyalty. In a culture emphasising the importance of social status (such as face consciousness in China), staying in a luxurious hotel is regarded as a symbol to demonstrate different social hierarchies of groups and in group status ( $\mathrm{Li}$ and $\mathrm{Su}, 2007)$. Consequently, consumers are more likely to relate the brand of a hotel to their social standing and thereby generate brand loyalty.

Secondly, this research investigated the comprehensive causal effects between customer experience and brand loyalty. The findings renew the knowledge of previous studies in three aspects. First, this study links the relationship between customer experience and brand loyalty. Previous studies normally focus on the connection between customer satisfaction and brand loyalty (e.g., Al-Msallam, 2015; Back and Parks, 2003). Most studies treated customer experience as a part of customer satisfaction (Verhoef et al., 2009). However, delivering customer experience goes beyond customer satisfaction, as satisfied customers may still defect to competitors (Mascarenhas et al., 2006). In some industries, organizations have slowly replaced the measurement of customer satisfaction scores with experience audits and implementation of customer experience management (Berry et al., 2002). Therefore, understanding the impact of customer experience on brand loyalty is useful for customer experience management in the hospitality industry. Second, this article verifies the intermediary role of brand trust and brand affect in the relation between hotel brand loyalty and customer experience. Back and Parks (2003) suggested brand loyalty has four consecutive phases, namely cognitive, affective, conative, and action. Therefore, customer experience does not directly relate to brand loyalty, as the $\mathrm{H}_{1}$ is rejected. Customer experience is confirmed to 
influence brand loyalty through a chain effect from cognitive phase (brand trust) to affective phase (brand affect), and then to brand loyalty. Third, brand trust does not directly relate to brand loyalty in the context of full-service hotel customer's experience. This result is different from findings from prior studies which are in different contexts (e.g., Kabadayi and Alan, 2012; Song et al., 2012). The comprehensive connections between customer experience and brand building-related factors are unveiled in this study.

Third, this study tested the moderating effect of brand involvement. The results show that the higher the degree of brand involvement, the stronger the impact of customer experience on brand trust, and brand affect. This study also testified that brand involvement does not have a direct moderating effect on the relationship between customer experience and brand loyalty. The possible explanation could be that experience is a moderator on the relationship of involvement and brand loyalty (Bennett et al., 2005), and the reverse direction does not exist. These findings extend the knowledge of brand building and give a more comprehensive explanation on the formation of brand loyalty.

\section{Theoretical Implications}

Theoretically, this study is one of the first few studies investigating the dimensionality of customer experience in the full-service hotel sector. Three unique dimensions have been identified, which are significant different from the factors of customer experience in the budget hotel. In studies of customer experience in budget hotels, basic services elements, such as cleanliness, smell, quietness, shower, temperature, maintenance, as well as location and visual appeal (Ren et al., 2016), are the most important attributes of a hotel. In contrast, this study 
shows the demands of customers staying in a full-service hotel exceed these basic functional elements. Experience related to customers' emotional response, self-esteem, and social belonging emerged to be important.

The study also contributes to the knowledge of the relationship between customer experience and brand loyalty. A comprehensive causal effects between customer experience and brand loyalty has been established with brand trust and brand affect as two mediators and brand involvement as the moderator. The model draws a comprehensive picture on how the customer experience can be directed to the building of loyalty for hotel brand.

\section{Practical Implications}

The study has important practical significance. First, hotel managers can improve customer experience by offering various functional attributes. While in a highly competitive market, functional experience gradually became the "hygiene factor" of Herzberg's two-factor theory for full-service hotels, while affective and social experience are the "incentive factors". Hence, hotel managers should pay more attention to creating affective and social experiences for their customers. For example, managers could emphasize the rank and status of their hotel brands when designing their marketing strategies in terms of suitable brand positioning, pricing, and promotion.

Second, the demonstration of intermediate roles of brand trust and affect could draw hotel managers' attention upon the promotion of hotel quality, capability and benevolence to customers through various channels. By doing so, customers' trust to the hotel brand can be better established. Meanwhile, establishing an emotional attachment between the customer and 
the brand is even more critical for building brand loyalty. Increasing the customer's interactions with hotels and building a brand story can shape a special feeling between the customers and the hotel brand. Besides the true feeling of customers, hotel managers who target customers could also try to stimulate customers' due feeling. That means, hotel managers can build the brand based on social norms and cultural values. Especially, domestic hotel brands can stimulate customers due feeling by emphasizing their localism. This finding could be particularly useful for the hotels focusing on domestic customers. This is an important aspect of hotel brand building in China.

Third, brand involvement also plays a role in brand building indirectly by moderating the relationships between customer experience and brand trust, and brand affect. Hotel managers should not only segment the market by demographic variables, but also need to identify and distinguish customers by their psychological types. Highly engaged customers with satisfactory experience have more positive attitudes and emotional connection to hotel brands. Communicating to customers with updated information, as well as organizing brand community can be a useful approach to increase their involvement with the brand.

\section{Limitations and Future Research}

The study has a number of limitations. This study did not have sufficient scale and thus did not attempt to analyze various sub-segments of the full-service hotel sector. In future research, a larger sample could be collected so that examination and comparison could be made on the different types of brands and customers, such as foreign versus domestic where differences identified in some studies (e.g., Ying et al., 2020). Further testing could also be done in other 
nations, different cultural settings and customers' backgrounds, to verify the measurement items and model. This article tested the intermediary and moderate roles of brand trust, affect and involvement, but other constructs, such as brand knowledge, brand personality, brand identification, may also play key roles in the mechanism of customer experience and brand loyalty. An even more comprehensive study can be considered in future studies.

\section{Reference:}

Agustin, C. and Singh, J. (2005), "Curvilinear effects of consumer loyalty determinants in relational exchanges", Journal of Marketing Research, Vol.42 No.1, pp.96-108.

Ali, F., Hussain, K. and Ragavan, N.A. (2014). "Memorable customer experience: examining the effects of customers experience on memories and loyalty in Malaysian resort hotels", Procedia-Social and Behavioral Sciences, Vol.144 No.1, pp.273-279.

Ali, F., Park, E.(O)., Kwon, J. and Chae, B.(K). (2019), "30 years of contemporary hospitality management: uncovering the bibliometrics and topical trends", International Journal of Contemporary Hospitality Management, Vol.31 No.7, pp.2641-2665. https://doi.org/10.1108/IJCHM-10-2018-0832

Al-Msallam, S. (2015), "Customer satisfaction and brand loyalty in the hotel industry", International Journal of Management Sciences and Business Research, Vol.4, pp.1-13.

Alnawas, I., and Hemsley-Brown, J. (2019). "Examining the key dimensions of customer experience quality in the hotel industry", Journal of Hospitality Marketing \& Management, Vol.28 No.7, pp.833-861.

Altinay, L. and Taheri, B. (2019), "Emerging themes and theories in the sharing economy: a critical note for hospitality and tourism", International Journal of Contemporary Hospitality Management, Vol. 31 No. 1, pp. 180-193. https://doi.org/10.1108/IJCHM02-2018-0171

Alsharo, M., Gregg, D. and Ramirez, R. (2016), "Virtual team effectiveness: the role of 
knowledge sharing and trust", Information and Management, Vol.54 No.4, pp.479-490. Anwar, A., Gulzar, A., Sohail, F.B. and Akram, S.N. (2011), "Impact of brand image, trust and affect on consumer brand extension attitude: the mediating role of brand loyalty", International Journal of Economics and Management Sciences, Vol.1 No.5, pp.73-79.

Ashley, C. and Leonard, H.A. (2009), "Betrayed by the buzz? Covert content and consumerbrand relationships", Journal of Public Policy and Marketing, Vol.28 No.2, pp.212-220.

Back, K.J. and Parks, S.C. (2003), "A brand loyalty model involving cognitive, affective, and conative brand loyalty and customer satisfaction", Journal of Hospitality and Tourism Research, Vol.27 No.4, pp.419-435.

Bahri-Ammari N., Van N.M., Ben K.H. and Chtioui J. (2016), "The effects of brand attachment on behavioral loyalty in the luxury restaurant sector", International Journal of Contemporary Hospitality Management, Vol.28 No.3, pp.559-585.

Bandalos, D.L. (2002), "The effects of item parceling on goodness-of-fit and parameter estimate bias in structural equation modeling", Structural Equation Modeling A Multidisplinary Journal, Vol.9 No.1, pp.78-102.

Bennett, R., Härtel, C.E. and McColl-Kennedy, J.R. (2005), "Experience as a moderator of involvement and satisfaction on brand loyalty in a business-to-business setting 02 314r", Industrial Marketing Management, Vol.34 No.1, pp.97-107.

Berry, L.L. and Carbone, L.P. (2007), "Build loyalty through experience management", Quality Progress, Vol.40 No.9, pp.26.

Berry, L.L., Carbone, L.P. and Haeckel, S.H. (2002), "Managing the total customer experience", MIT Sloan Management Review, Vol.43 No.3, pp.85-89.

Berry, L.L., Wall, E.A., and Carbone, L.P. (2006), "Managing service experience clues", Academy of Management Perspectives, Vol.20 No.2, pp.1-13.

Bian, X., and Haque, S. (2020), "Counterfeit versus original patronage: do emotional brand attachment, brand involvement, and past experience matter?", Journal of Brand Management, pp.1-14.

Biedenbach, G. and Marell, A. (2010), "The impact of customer experience on brand equity in a business-to-business services setting", Journal of Brand Management, Vol.17 No.6, 
pp.446-458.

Bravo, R., Martinez, E. and Pina, J.M. (2019), "Effects of service experience on customer responses to a hotel chain", International Journal of Contemporary Hospitality Management, Vol.31 No.1, pp.389-405.

Casalo, L.V., Flavián, C. and Guinalíu, M. (2007), "The influence of satisfaction, perceived reputation and trust on a consumer's commitment to a website", Journal of Marketing Communications, Vol.13 No.1, pp.1-17.

Cetin, G. and Dincer, F.I. (2014), "Influence of customer experience on loyalty and word-ofmouth in hospitality operations", Anatolia: An International Journal of Tourism and Hospitality Research, Vol.25 No.2, pp.181-194.

Cetin, G. and Walls, A. (2016), "Understanding the customer experiences from the perspective of customers and hotel managers: empirical findings from luxury hotels in Istanbul, Turkey", Journal of Hospitality Marketing and Management, Vol.25 No.4, pp.395-424.

Chaudhuri, A. (1997), "Consumption emotion and perceived risk: a macro-analytic approach", Journal of Business Research, Vol.39 No.2, pp.81-92.

Chaudhuri, A. and Holbrook, M.B. (2001), "The chain of effects from brand trust and brand affect to brand performance: the role of brand loyalty", Journal of Marketing, Vol.65 No.2, pp.81-93.

Chepngetich, B., Ouma, O.K. and Aila, F.O. (2019), "Influence of customer experience dimensions on purchase behavior in Kenyan hotels", European Journal of Business and Management, Vol.11 No.21, pp.50-62.

Chin, W.W. (1998), "The partial least squares approach to structural equation modeling", Modern Methods for Business Research, Vol.295 No.2, pp.295-336.

China Hotel Association.(2020), China hotel industry development report 2020. Beijing.

Chinese Ministry of Culture and Tourism. (2020), Statistical Communique on Cultural and Tourism Development 2019. Beijing.

Dahlgren, S. (2011), "Brand loyalty and involvement in different customer levels of a service concept brand", Master's Thesis, Aalto University.

Delgado-Ballester, E. and Luis Munuera-Alemán, J. (2001), "Brand trust in the context of 
consumer loyalty", European Journal of Marketing, Vol.35 No.11/12, pp.1238-1258.

Delgado-Ballester, E., Munuera-Aleman, J.L. and Yague-Guillen, M.J. (2003), "Development and validation of a brand trust scale", International Journal of Market Research, Vol.45 No.1, pp.35-54.

Dick, A.S. and Basu, K. (1994), "Customer loyalty: toward an integrated conceptual framework", Journal of the Academy of Marketing Science, Vol.22 No.2, pp.99-113.

El Naggar, R.A.A. and Bendary, N. (2017), "The impact of experience and brand trust on brand loyalty, while considering the mediating effect of brand equity dimensions, an empirical study on mobile operator subscribers in Egypt", The Business and Management Review, Vol.9 No.2, pp.16-25.

Foroudi, P., Jin, Z., Gupta, S., Melewar, T. and Foroudi, M.M. (2016), "Influence of innovation capability and customer experience on reputation and loyalty", Journal of Business Research, Vol.69 No.11, pp.4882-4889.

Gecti, F. and Zengin, H. (2013), "The relationship between brand trust, brand affect, attitudinal loyalty and behavioral loyalty: a field study towards sports shoe consumers in turkey", International Journal of Marketing Studies, Vol.5 No.2, pp.111-119.

Gentile, C., Spiller, N. and Noci, G. (2007), "How to sustain the customer experience: an overview of experience components that co-create value with the customer", European Management Journal, Vol.25 No.5, pp.395-410.

Gundlach, G.T., Achrol, R.S. and Mentzer, J.T. (1995), "The structure of commitment in exchange", Journal of Marketing, Vol.59 No.1, pp.78-92.

Hair, J.F., Christian, M.R. and Sarstedt, M. (2011), "PLS-SEM: Indeed a silver bullet." Journal of Marketing Theory and Practice, Vol.19 No.2, pp.139-152.

Hair, J.F., Hult, G.T.M., Ringle, C.M. and Sarstedt, M. (2014), A primer on partial least squares structural equation modeling (PLS-SEM). SAGE, California.

Harkison, T., Hemmington, N., and Hyde, K. F. (2018). "Creating the luxury accommodation experience: case studies from New Zealand", International Journal of Contemporary Hospitality Management, Vol.30 No.3, pp.1724-1740.

Hemmington, N. (2007). "From service to experience: understanding and defining the 
hospitality business", The Service Industries Journal, Vol.27 No.6, pp.747-755.

Hemsley-Brown, J. and Alnawas, I. (2016), "Service quality and brand loyalty: the mediation effect of brand passion, brand affection and self-brand connection", International Journal of Contemporary Hospitality Management, Vol.28 No.12, pp.2771-2794.

He, X.J. (2008), "The structure of consumers' affects in the context of the Chinese culture and their effects on the equity of china's and foreign brands", Management World, Vol.6, pp.95-108.

Heung, V.C.S and Lam, T. (2003), "Customer complaint behaviour towards hotel restaurant services", International Journal of Contemporary Hospitality Management, Vol.15 No.5, pp.283-289.

Hochgraefe, C., Faulk, S. and Vieregge, M. (2012), "Links between swiss hotel guests' product involvement and brand loyalty", Journal of Hospitality Marketing and Management, Vol.21 No.1, pp.20-39.

Hosseini, R.S. and Zainal, A. (2016), "The effects of indirect experience of hotel customers on brand association and loyalty in Iran". Proceedings of the 1st AAGBS International Conference on Business Management 2014 (AiCoBM 2014), Springer.

Hosseini, R.S., Zainal, A. and Sumarjan, N. (2015), "The effects of service performance of hotel customers on quality of experience and brand loyalty in Iran", Procedia-Social and Behavioral Sciences, Vol.201, pp.156-164.

Huang, C.C. (2017), "The impacts of brand experiences on brand loyalty: mediators of brand love and trust", Management Decision, Vol.55 No.5, pp.915-934.

Huang, C.T. and Chen, P.T. (2010), "Do reward programs truly build loyalty for lodging industry?", International Journal of Hospitality Management, Vol.29 No.1, pp.128-135.

Hussein, A.S., Hapsari, R.D.V. and Yulianti, I. (2018), "Experience quality and hotel boutique customer loyalty: mediating role of hotel image and perceived value", Journal of Quality Assurance in Hospitality and Tourism, Vol.19 No.4, pp.442-459.

Iacobucci, D. (2010), "Structural equations modeling: fit indices, sample size, and advanced topics." Journal of Consumer Psychology, Vol.20 No.1, pp.90-98.

Iglesias, O., Singh, J.J. and Batistafoguet, J.M. (2011), "The role of brand experience and 
affective commitment in determining brand loyalty", Journal of Brand Management, Vol.18 No.8, pp.570-582.

Jain, R., Aagja, J. and Bagdare, S. (2017), "Customer experience-a review and research agenda", Journal of Service Theory and Practice, Vol.27 No.3, pp.642-662.

Kabadayi, E.T. and Alan, A.K. (2012), "Brand trust and brand affect: their strategic importance on brand loyalty", Journal of Global Strategic Management, Vol.11 No.6, pp.81-88.

Kang, J., Manthiou, A., Sumarjan, N. and Tang, L. (2017), "An investigation of brand experience on brand attachment, knowledge, and trust in the lodging industry", Journal of Hospitality Marketing and Management, Vol.26 No.1, pp.1-22.

Kim-Soon, N., Rahman, A. and Visvalingam, L. (2014), "Servqual: can it be used to differentiate guest's perception of service quality of 3 star from a 4 star hotel", International Business Research, Vol.7 No.7, pp.37-47.

Kim, I., Jeon, S.M. and Hyun, S.S. (2012), "Chain restaurant patrons' well-being perception and dining intentions: the moderating role of involvement", International Journal of Contemporary Hospitality Management, Vol.24 No.3, pp.402-429.

Kim, J. and Sung, Y. (2009), "Dimensions of purchase-decision involvement: affective and cognitive involvement in product and brand", Journal of Brand Management, Vol.16 No.8, pp.504-519.

Kim, W.G., Lee, S. and Lee, H.Y. (2007), "Co-branding and brand loyalty", Journal of Quality Assurance in Hospitality and Tourism, Vol.8 No.2, pp.1-23.

Knox, S. and Walker, D. (2003), "Empirical developments in the measurement of involvement, brand loyalty and their relationship in grocery markets", Journal of Strategic Marketing, Vol.11 No.4, pp.271-286.

Knutson, B.J., Beck, J.A., Kim, S. and Cha, J. (2009), "Identifying the dimensions of the guest's hotel experience", Cornell Hospitality Quarterly, Vol.50 No.1, pp.44-55.

Little, T.D., Cunningham, W.A., Shahar, G. and Widaman, K.F. (2002), "To parcel or not to parcel: exploring the question, weighing the merits", Structural Equation Modeling A Multidisciplinary Journal, Vol.9 No.2, pp.151-173.

Li, J.J. and Su, C. (2007), "How face influences consumption", International Journal of Market 
Research, Vol.49 No.2, pp.237-256.

Lin, H., Zhang, M. and Gursoy, D. (2020), "Impact of nonverbal customer-to-customer interactions on customer satisfaction and loyalty intentions", International Journal of Contemporary Hospitality Management, Vol.32 No.5, pp.1967-1985. https://doi.org/10.1108/IJCHM-08-2019-0694

Lockshin, L.S., Spawton, A.L., and Macintosh, G. (1997). "Using product, brand and purchasing involvement for retail segmentation", Journal of Retailing and Consumer Services, Vol.4 No.3, pp.171-183.

Luo, J.(G)., Wong, I.A., King, B., Liu, M.T. and Huang, G. (2019), "Co-creation and codestruction of service quality through customer-to-customer interactions: why prior experience matters", International Journal of Contemporary Hospitality Management, Vol. 31 No. 3, pp. 1309-1329. https://doi.org/10.1108/IJCHM-12-2017-0792

Maghzi, A., Abbaspour, B., Eskandarian, M. and Hamid, A.B.A. (2011), "Brand trust in hotel industry: influence of service quality and customer satisfaction". 2nd International Conference on Business, Economics and Tourism Management, Singapore, Vol.24, pp.42-46.

Malik, M.E., Ghafoor, M.M. and Hafiz, K.I. (2012), "Impact of brand image, service quality and price on customer satisfaction in Pakistan telecommunication sector", International Journal of Business and Social Science, Vol.3 No.23, pp.123-129.

Mascarenhas, O.A., Kesavan, R. and Bernacchi, M. (2004), "Customer value-chain involvement for co-creating customer delight", Journal of Consumer Marketing, Vol.21 No.7, pp.486-496.

Mascarenhas, O.A., Kesavan, R. and Bernacchi, M. (2006), "Lasting customer loyalty: a total customer experience approach", Journal of Consumer Marketing, Vol.23 No.7, pp.397405.

Mattila, A.S. (1999), "An analysis of means-end hierarchies in cross-cultural context", Journal of Hospitality and Leisure Marketing, Vol.6 No.2, pp.19-28.

Matzler, K., Bidmon, S. and Grabner-Kräuter, S. (2006), "Individual determinants of brand affect: the role of the personality traits of extraversion and openness to experience", 
Journal of Product and Brand Management, Vol.15 No.7, pp.427-434.

Matzler, K., Grabner-Kräuter, S. and Bidmon, S. (2008), "Risk aversion and brand loyalty: the mediating role of brand trust and brand affect", Journal of Product and Brand Management, Vol.17 No.3, pp.154-162.

Monkhouse, L.L., Barnes, B.R. and Stephan, U. (2012), "The influence of face and group orientation on the perception of luxury goods: A four market study of East Asian consumers", International Marketing Review, Vol.29 No.6 pp.647-672.

Ndubisi, N.O. (2007), "Relationship quality antecedents: the Malaysian retail banking perspective", International Journal of Quality and Reliability Management, Vol.24 No.28, pp. 829-845.

Oliver, R.L. (1999), “Whence consumer loyalty?”, Journal of Marketing, Vol.63 No.4, pp.3344.

Ong, C.H., Lee, H.W. and Ramayah, T. (2018), "Impact of brand experience on loyalty", Journal of Hospitality Marketing and Management, Vol.27 No.7, pp.755-774.

Oyedeji, T. and Hou, J. (2010), "The effects of cable news outlets 'customer-based brand equity on audiences' evaluation of the credibility of their online brand extensions", Journal of Media Business Studies, Vol.7 No.1, pp.41-58.

Pine II, B.J. and Gilmore, J.H. (1998), "Welcome to the experience economy", Harvard Business Review, Vol.76, pp.97-105.

Prasad, K. and Dev, C.S. (2000), "Managing hotel brand equity: a customer-centric framework for assessing performance", The Cornell Hotel and Restaurant Administration Quarterly, Vol.41 No.3, pp.22-24.

Rather, R. and Sharma, J. (2016), "Brand loyalty with hospitality brands: the role of customer brand identification, brand satisfaction and brand commitment", Pacific Business Review International, Vol.1 No.3, pp.76-86.

Ren, L., Qiu, H., Wang, P. and Lin, P.M. (2016), "Exploring customer experience with budget hotels: dimensionality and satisfaction", International Journal of Hospitality Management, Vol.52, pp.13-23.

Richards, L. (2009), Handling qualitative data: a practical guide, SAGE. 
Schmitt, B. (1999), "Experiential marketing: a new framework for design and communications", Design Management Journal (Former Series), Vol.10 No.2, pp.1016.

Shin, M., Back, K.-J., Lee, C.-K. and Lee, Y.-S. (2020), "Enhancing customer-brand relationship by leveraging loyalty program experiences that foster customer-brand identification", International Journal of Contemporary Hospitality Management, Vol. 32 No. 12, pp. 3991-4016. https://doi.org/10.1108/IJCHM-06-2020-0550

Shiue, Y.C. and Li, L.S.H. (2013), "Brand involvement in retaining customers despite dissatisfaction", Social Behavior and Personality: An International Journal, Vol.41 No.4, pp.643-650.

Shobri, M., Diyana, N. and Putit, L. (2015), "Building guest loyalty: the role of guest based brand equity and guest experience in resort hotel industry", Advanced Science Letters, Vol.21 No.5, pp.1605-1609.

So, K.K.F. and King, C. (2010), "When experience matters: building and measuring hotel brand equity: The customers' perspective", International Journal of Contemporary Hospitality Management, Vol.22 No.5, pp.589-608.

So, K.K.F., King, C., Sparks, B.A. and Wang, Y. (2013), "The influence of customer brand identification on hotel brand evaluation and loyalty development", International Journal of Hospitality Management, Vol.34, pp.31-41.

So, K.K.F., King, C., Sparks, B.A. and Wang, Y. (2016), "The role of customer engagement in building consumer loyalty to tourism brands", Journal of Travel Research, Vol.55 No.1, pp. 64-78.

Soedarto, T., Kurniawan, G.S.A. and Sunarsono, R.J. (2019), "The parceling of loyalty: brand quality, brand affect, and brand trust effect on attitudinal loyalty and behavioral loyalty", Academy of Strategic Management Journal, Vol.18 No.1, pp.1-15.

Song, Y., Hu, W.M. and Kim, M. (2012), "Brand trust and affect in the luxury brand-customer relationship", Social Behavior and Personality: An International Journal, Vol.40 No.2, pp.331-338.

Su, Y., Fang, L.Z. and Chen, Y.Y. (2018), "The origin and development of brand emotion- 
based on emotional marketing literature review", China Business and Market, Vol.32 No.6, pp.53-61.

Suh, J.C. and Youjae, Y. (2006), "When brand attitudes affect the customer satisfaction-loyalty relation: the moderating role of product involvement", Journal of Consumer Psychology, Vol.16 No.2, pp.145-155.

Sunyansanoa, S., Farquhar, J. and Czarnecka, B. (2013), "Consumer's post-purchase evaluation for repurchase intentions of credence products: empirical evidence from Thailand", Journal of Retailing, Vol.76 No.2, pp.193-218.

Swaminathan, V., Fox, R.J. and Reddy, S.K. (2001), "The impact of brand extension introduction on choice", Journal of Marketing, Vol.65 No.4, pp.1-15.

Swoboda, B., Haelsig, F., Schramm-Klein, H. and Morschett, D. (2009), "Moderating role of involvement in building a retail brand", International Journal of Retail and Distribution Management, Vol.37 No.11, pp.952-974.

Tepeci, M. (1999), "Increasing brand loyalty in the hospitality industry", International Journal of Contemporary Hospitality Management, Vol.11 No.5, pp.223-230.

Urbach, N. and Ahlemann, F. (2010), "Structural equation modeling in information systems research using partial least squares", Journal of Information Technology Theory and Application, Vol.11 No.2, pp.5-40.

Valenzuela, F. and Vásquez-Párraga, A. (2006), "Trust and commitment as mediating variables in the relationship between satisfaction and hotel guest loyalty", Panorama Socioeconomico, Vol.24 No.32, pp.18-23.

Vazifehdoost, H., Rahnama, A. and Mousavian, S.J. (2014), "Evaluation of the impact of brand purchase involvement, satisfaction, experience and brand trust on loyalty to brand", Mediterranean Journal of Social Sciences, Vol.5 No.20, pp.3054-3063.

Verhoef, P.C., Lemon, K.N., Parasuraman, A., Roggeveen, A., Tsiros, M. and Schlesinger, L.A. (2009), "Customer experience creation: determinants, dynamics and management strategies", Journal of Retailing, Vol.85 No.1, pp.31-41.

Walls, A.R. (2013), "A cross-sectional examination of hotel consumer experience and relative effects on consumer values", International Journal of Hospitality Management, Vol.32, 
pp.179-192.

Walls, A.R., Okumus, F., Wang, Y.C. and Kwun, D.J. (2011), "An epistemological view of consumer experiences", International Journal of Hospitality Management, Vol.30 No.1, pp. 10-21.

Walls, A., Okumus F., Wang, Y.C. and Kwun, D.J. (2011), "Understanding the consumer experience: an exploratory study of luxury hotels", Journal of Hospitality Marketing \& Management, Vol.20 No.2, pp.166-197.

Wang, T.S. (2020), Report on the development of Chinese brand strategy (2019-2020), Social Sciences Academic Press, Beijing.

Wang, C. Z. and Zhou, X. C. (2011), "Effect of symbolic brand: from meaning to loyalty", Journal of Management Science, Vol. 24 No. 4, pp.41-53.

Wang, W., Ying, S., Mejia, C., Wang, Y., Qi, X. and Chan, J.H. (2020), "Independent travelers' niche hotel booking motivations: the emergence of a hybrid cultural society", International Journal of Hospitality Management, Vol.89, pp.102573.

Wen, Z.L., Hau, K.T. and Marsh, H.W. (2004), "Structural equation model testing: cutoff criteria for goodness of fit indices and chi-square test", Acta Psychologica Sinica, Vol.36 No.2, pp.186-194.

Wilkins, H., Merrilees, B. and Herington, C. (2009), "The determinants of loyalty in hotels", Journal of Hospitality Marketing and Management, Vol.19 No.1, pp.1-21.

Woodside, A.G. and Walser, M.G. (2007), "Building strong brands in retailing", Journal of Business Research, Vol.60 No.1, pp.1-10.

World Tourism Organization.(2019), International tourism highlights. available at: https://www.e-unwto.org/doi/pdf/10.18111/9789284421152 (accessed 20 December 2020)

Wu, M.L. (2009), Structural Equation Model: AMOS Operation and Application, Chongqing University Press.

Wu, S.H. and Gao, Y. (2019), "Understanding emotional customer experience and co-creation behaviours in luxury hotels", International Journal of Contemporary Hospitality 
Management, Vol. 31 No. 11, pp. 4247-4275. https://doi.org/10.1108/IJCHM-04-20180302

Xu, B.J. and Chan, A. (2010), "A conceptual framework of hotel experience and customerbased brand equity: some research questions and implications", International Journal of Contemporary Hospitality Management, Vol.22 No.2, pp.174-193.

Yang, Y. and Chan, A. (2010), "An exploration of customer experience in resort hotels and its empirical enlightenment", Tourism Tribune, Vol.25 No.4, pp.49-53.

Ying, S., Chan, J.H. and Qi, X. (2020), "Why are Chinese and North American guests satisfied or dissatisfied with hotels? An application of big data analysis", International Journal of Contemporary Hospitality Management, Vol.32 No.10, pp.249-3269.

Yoon, S. J., and Lee, H. J. (2017). "Does customer experience management pay off? Evidence from local versus global hotel brands in South Korea", Journal of Hospitality Marketing \& Management, Vol.26 No.6, pp.585-605.

Yuan, D. H. (2007), “A review and outlook on the research on brand trust", Psychological Science, Vol. 30 No. 2, pp.434-437.

Zaichkowsky, J.L. (1985), "Measuring the involvement construct", Journal of Consumer Research, Vol.12 No.3, pp.341-352.

Zeithaml, V.A., Berry, L. and Parasuraman, A. (1996), “The behavioral consequences of service quality", Journal of Marketing Management, Vol.60, pp.31-46. 


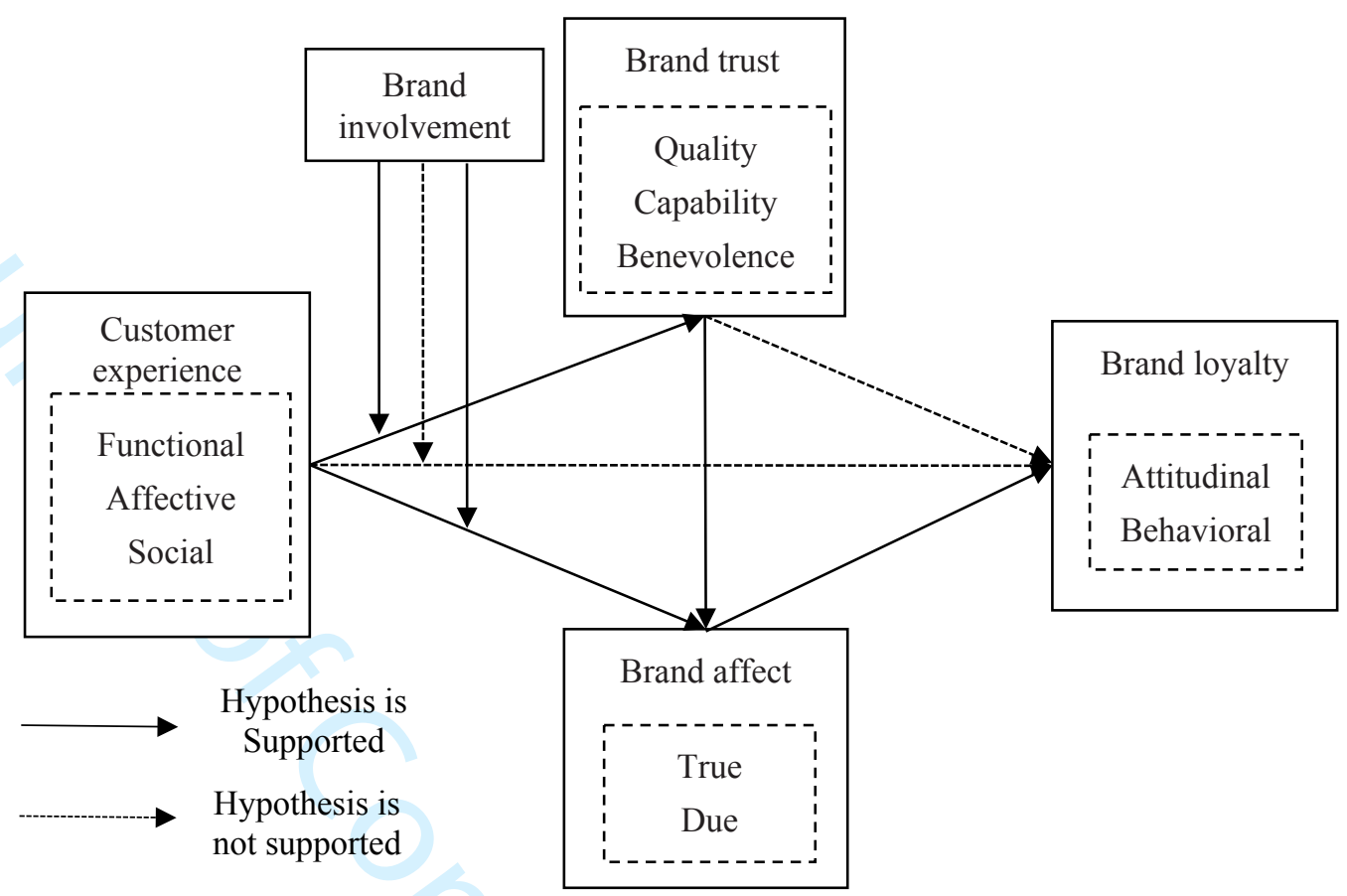

Figure 1: The theoretical model of chain effects between hotel customer experience and brand loyalty 
Table 1: Scale of hotel customer experience bases on a small sample survey

\begin{tabular}{|c|c|c|c|c|c|c|}
\hline \multicolumn{2}{|c|}{ Dimensions } & $\begin{array}{c}\text { Factor Loading } \\
\text { (EFA) }\end{array}$ & Cronbach' $\alpha$ & $\begin{array}{l}\text { Factor Loading } \\
\text { (CFA) }\end{array}$ & $\begin{array}{c}\text { Composite } \\
\text { reliability ( CR ) }\end{array}$ & AVE \\
\hline \multirow{5}{*}{ Functional } & A1/FE1 & .808 & \multirow{5}{*}{0.858} & .812 & \multirow{5}{*}{0.8587} & \multirow{5}{*}{0.8270} \\
\hline & A4/FE2 & .831 & & .803 & & \\
\hline & A5/FE3 & .786 & & .818 & & \\
\hline & A7/FE4 & .667 & & .799 & & \\
\hline & A8/FE5 & .702 & & .813 & & \\
\hline \multirow{4}{*}{ Affective } & B11/AE1 & .828 & \multirow{4}{*}{0.837} & .878 & \multirow{4}{*}{0.8378} & \multirow{4}{*}{0.7611} \\
\hline & $\mathrm{B} 12 / \mathrm{AE} 2$ & .816 & & .884 & & \\
\hline & B13/AE3 & .868 & & .815 & & \\
\hline & B14/AE4 & .809 & & .858 & & \\
\hline \multirow{6}{*}{ Social } & $\mathrm{C} 21 / \mathrm{SE} 1$ & .803 & \multirow{6}{*}{0.865} & .844 & \multirow{6}{*}{0.8687} & \multirow{6}{*}{0.8856} \\
\hline & C22/SE2 & .795 & & .859 & & \\
\hline & C24/SE3 & .698 & & .824 & & \\
\hline & C25/SE4 & .791 & & .837 & & \\
\hline & C26/SE5 & .802 & & .852 & & \\
\hline & C28/SE6 & .784 & & .851 & & \\
\hline
\end{tabular}

Table 2: The profile of samples $(\mathrm{N}=732)$

\begin{tabular}{|c|c|c|c|}
\hline Demographics & Category & Frequency & Percentage $\%$ \\
\hline \multirow{2}{*}{ Gender } & Male & 449 & $61 \%$ \\
\hline & Female & 283 & $39 \%$ \\
\hline \multirow{5}{*}{ Age } & $19-29$ & 45 & $6 \%$ \\
\hline & $30-39$ & 217 & $30 \%$ \\
\hline & $40-49$ & 308 & $42 \%$ \\
\hline & $50-59$ & 104 & $14 \%$ \\
\hline & Over 60 & 58 & $8 \%$ \\
\hline \multirow{5}{*}{ Income (RMB) } & Under 5,000 & 27 & $4 \%$ \\
\hline & $5,000-9,999$ & 124 & $17 \%$ \\
\hline & $10,000-29,999$ & 226 & $31 \%$ \\
\hline & $30,000-50,000$ & 287 & $39 \%$ \\
\hline & Over 50,000 & 68 & $x^{2}$ \\
\hline \multirow{4}{*}{ Education } & High school or lower & 66 & $9 \%$ \\
\hline & Diploma & 153 & $21 \%$ \\
\hline & Bachelor & 419 & $57 \%$ \\
\hline & Postgraduates & 94 & $13 \%$ \\
\hline
\end{tabular}


Table 3: Validity and reliability of scales

\begin{tabular}{|c|c|c|c|c|c|c|c|c|}
\hline Construct & Item & Mean & $\begin{array}{l}\text { Factor } \\
\text { Loading } \\
\text { (EFA) }\end{array}$ & $\begin{array}{l}\text { Cronb } \\
\text { ach' } \alpha\end{array}$ & $\begin{array}{l}\text { Factor } \\
\text { Loading } \\
\text { (CFA) }\end{array}$ & $\begin{array}{c}\text { Composite } \\
\text { reliability } \\
(\mathrm{CR})\end{array}$ & $\begin{array}{l}\text { D.G. } \\
\text { Rho }\end{array}$ & AVE \\
\hline \multirow{5}{*}{$\begin{array}{l}\text { Functional } \\
\text { Experience }\end{array}$} & FE1 & 5.82 & 0.600 & \multirow{5}{*}{0.921} & 0.809 & \multirow{5}{*}{0.934} & \multirow{5}{*}{0.913} & \multirow{5}{*}{0.740} \\
\hline & FE2 & 6.02 & 0.679 & & 0.881 & & & \\
\hline & FE3 & 5.98 & 0.645 & & 0.896 & & & \\
\hline & FE4 & 5.97 & 0.681 & & 0.887 & & & \\
\hline & FE5 & 6.05 & 0.680 & & 0.825 & & & \\
\hline \multirow{4}{*}{$\begin{array}{c}\text { Affective } \\
\text { Experience } \\
(\mathrm{AE})\end{array}$} & EE1 & 5.83 & 0.617 & \multirow{4}{*}{0.917} & 0.885 & \multirow{4}{*}{0.942} & \multirow{4}{*}{0.918} & \multirow{4}{*}{0.802} \\
\hline & EE2 & 5.90 & 0.595 & & 0.913 & & & \\
\hline & EE3 & 5.82 & 0.535 & & 0.922 & & & \\
\hline & EE4 & 5.67 & 0.564 & & 0.860 & & & \\
\hline \multirow{6}{*}{$\begin{array}{c}\text { Social } \\
\text { Experience } \\
(\mathrm{SE})\end{array}$} & SE1 & 5.59 & 0.602 & \multirow{6}{*}{0.927} & 0.867 & \multirow{6}{*}{0.945} & \multirow{6}{*}{0.927} & \multirow{6}{*}{0.774} \\
\hline & SE2 & 5.57 & 0.623 & & 0.906 & & & \\
\hline & SE3 & 5.80 & 0.633 & & 0.869 & & & \\
\hline & SE4 & 5.65 & 0.670 & & 0.900 & & & \\
\hline & SE5 & 5.63 & 0.644 & & 0.858 & & & \\
\hline & SE6 & 5.70 & 0.453 & & - & & & \\
\hline $\begin{array}{c}\text { Customer } \\
\text { Experience }\end{array}$ & & & & 0.893 & & 0.934 & 0.895 & 0.825 \\
\hline \multirow{5}{*}{$\begin{array}{l}\text { Quality } \\
\text { Trust } \\
\text { ( QT ) }\end{array}$} & QT1 & 5.91 & 0.490 & \multirow{5}{*}{0.882} & - & & & \\
\hline & QT2 & 5.99 & 0.531 & & 0.803 & & & \\
\hline & QT3 & 6.03 & 0.625 & & 0.869 & 0.885 & 0.919 & 0.740 \\
\hline & QT4 & 6.06 & 0.693 & & 0.911 & & & \\
\hline & QT5 & 5.99 & 0.675 & & 0.855 & & & \\
\hline & CT1 & 5.97 & 0.719 & & 0.896 & & & \\
\hline Capability & CT2 & 5.94 & 0.706 & & 0.885 & & & \\
\hline Trust & CT3 & 6.01 & 0.691 & 0.925 & 0.907 & 0.926 & 0.943 & 0.769 \\
\hline ( CT ) & CT4 & 5.95 & 0.665 & & 0.864 & & & \\
\hline & CT5 & 5.84 & 0.617 & & 0.832 & & & \\
\hline & BT1 & 5.90 & 0.665 & & 0.864 & & & \\
\hline Benevolenc & BT2 & 5.90 & 0.730 & & 0.904 & & & \\
\hline $\mathrm{e}$ & BT3 & 5.85 & 0.680 & 0.882 & 0.890 & 0.885 & 0.919 & 0.740 \\
\hline ( BT ) & BT4 & 6.00 & 0.726 & & 0.889 & & & \\
\hline & BT5 & 5.90 & 0.656 & & 0.844 & & & \\
\hline Brand Trust & & & & 0.934 & & 0.934 & 0.958 & 0.883 \\
\hline & RA1 & 5.49 & 0.552 & & 0.877 & & & \\
\hline True Affect & RA2 & 5.64 & 0.565 & 0019 & 0.907 & 0019 & 0019 & 0942 \\
\hline ( RA ) & RA3 & 5.60 & 0.659 & 0.919 & 0.909 & 0.919 & 0.919 & 0.942 \\
\hline & RA4 & 5.61 & 0.666 & & 0.892 & & & \\
\hline & DA1 & 5.67 & 0.648 & & 0.877 & & & \\
\hline Due Affect & DA2 & 5.46 & 0.750 & 0921 & 0.912 & 0927 & 0945 & 0810 \\
\hline ( DA ) & DA3 & 5.45 & 0.731 & & 0.915 & & & \\
\hline & DA4 & 5.49 & 0.755 & & 0.896 & & & \\
\hline $\begin{array}{l}\text { Brand } \\
\text { Affect }\end{array}$ & & & & 0.900 & & 0.900 & 0.952 & 0.909 \\
\hline Attitudinal & AL1 & 5.43 & 0.752 & & 0.905 & & & \\
\hline Loyalty & AL2 & 5.46 & 0.804 & 0.899 & 0.937 & 0.900 & 0.937 & 0.832 \\
\hline$(\mathrm{AL})$ & AL3 & 5.50 & 0.754 & & 0.894 & & & \\
\hline Behavioral & BL1 & 5.61 & 0.744 & & 0.909 & & & \\
\hline Loyalty & BL2 & 5.68 & 0.680 & 0.902 & 0.933 & 0.903 & 0.939 & 0.837 \\
\hline ( BL ) & BL3 & 5.72 & 0.643 & & 0.902 & & & \\
\hline $\begin{array}{c}\text { Brand } \\
\text { Loyalty }\end{array}$ & & & & 0.876 & & 0.876 & 0.941 & 0.889 \\
\hline & BI1 & 5.56 & 0.729 & & 0.885 & & & The \\
\hline & $\mathrm{BI} 2$ & 5.51 & 0.747 & & 0.841 & & & \\
\hline Involvement & $\mathrm{BI} 3$ & 5.58 & 0.740 & 0056 & 0.866 & 0057 & 0063 & 0741 \\
\hline ( $\mathrm{BI})$ & BI4 & 5.67 & 0.668 & 0.750 & 0.880 & 0.751 & 0.705 & 0.141 \\
\hline ( D1) & BI5 & 5.65 & 0.713 & & 0.883 & & & \\
\hline & BI6 & 5.77 & 0.604 & & 0.844 & & & \\
\hline
\end{tabular}


Table 4: The causal relationships between customer experience and brand loyalty

Table 5: Outcomes of the structure model test

\begin{tabular}{lccc}
\hline \multicolumn{1}{c}{ Paths } & Hypotheses & Path coefficient & $\mathrm{P}$ \\
\hline Customer Experience $\rightarrow$ Brand Loyalty & $\mathrm{H}_{1}$ & -0.011 & 0.783 \\
\hline Customer Experience $\rightarrow$ Brand Trust & $\mathrm{H}_{2}$ & 0.619 & $* * *$ \\
\hline Customer Experience $\rightarrow$ Brand Affect & $\mathrm{H}_{3}$ & 0.237 & 0.171 \\
\hline Customer Experience $\rightarrow$ Brand Trust $\rightarrow$ Brand Loyalty & $\mathrm{H}_{4}$ & 0.038 & $* * *$ \\
\hline Customer Experience $\rightarrow$ Brand Affect $\rightarrow$ Brand Loyalty & $\mathrm{H}_{5}$ & 0.116 & $* * *$ \\
\hline $\begin{array}{l}\text { Customer Experience } \rightarrow \text { Brand Trust } \rightarrow \text { Brand Affect } \rightarrow \text { Brand Loyalty } \\
\text { Moderating Role of Brand Involvement: }\end{array}$ & $\mathrm{H}_{6}$ & 0.062 & $* * *$ \\
between Customer Experience and Brand Trust & $\mathrm{H}_{\mathrm{a}}$ & -0.038 & $* * *$ \\
\hline $\begin{array}{l}\text { Moderating Role of Brand Involvement: } \\
\text { between Customer Experience and Brand Affect }\end{array}$ & $\mathrm{H} 7_{\mathrm{b}}$ & 0.045 & -0.006 \\
\hline $\begin{array}{l}\text { Moderating Role of Brand Involvement: } \\
\text { between Customer Experience and Brand Loyalty }\end{array}$ & $\mathrm{H} 7_{\mathrm{c}}$ & 0.376 \\
\hline
\end{tabular}

Note: $* * * p<0.01$ 


\section{INTERNATIONAL JOURNAL OF CONTEMPORARY HOSPITALITY MANAGEMENT}

Author Response Form

6

7

8

9

When revising your paper, please prepare this report explaining how you have responded to each reviewer's comments and suggestions specifically.

EXECUITV EDITOR

\begin{tabular}{|l|}
\hline Suggestions/comments from the editor \\
\hline 1. Include a structured abstract in page 1 of the main \\
document and make sure that it includes all the required \\
subsections including Purpose, Methodology, Findings, \\
Implications and Originality.
\end{tabular}

2. When there are three or more authors, you need to use Adam et al., XXXX (or Adam et al., XXXX) format for the first time and after. You should list references within text in an alphabetical order.

3. There should be four sub-sections under this section: (1) Conclusions, (2) Theoretical Implications, (3) Practical Implications and (4) Limitations and Future Research.

4. Incorporate more recent and relevant references published in recent months/years
Response from the Author(s)

Thanks for your comments.

We have modified the abstract following the editor's suggestion and constructed the abstract into five sections, namely purpose, methodology, findings, practice implication and originality. The wording of the abstract also has been revised (See page 1 on the main document).

Thank you for your specific comments.

We have carefully checked the format of citations and corrected them following the journal's requirement.

Thank you for this suggestion.

We have reconstructed the section of Conclusions. Now there are four sub-sections (i.e., Discussion and conclusions, Theoretical implication, Practical implication, Limitation and future research), exactly following your suggestion. These modifications improve the clarity and the structure of the Conclusions section. We reemphasized the theoretical contributions of this study . Thanks for your comments.

More recent and relevant references have been included into the manuscript. The list is as the below.

Ali, F., Park, E.(O)., Kwon, J. and Chae, B.(K). (2019), "30 years of contemporary hospitality management: Uncovering the bibliometrics and topical trends", International Journal of Contemporary Hospitality Management, Vol. 31 No. 7, pp. 2641-2665. https://doi.org/10.1108/IJCHM-10-2018-0832

Lin, H., Zhang, M. and Gursoy, D. (2020), "Impact of nonverbal customer-to-customer interactions on customer satisfaction and loyalty intentions", International Journal of Contemporary Hospitality Management, Vol. 32 No. 5, pp. 1967-1985. https://doi.org/10.1108/IJCHM-08-20190694

Bravo, R., Martinez, E. and Pina, J.M. (2019), "Effects of service experience on customer responses to a hotel chain", International Journal of Contemporary Hospitality Management, Vol. 31 No. 1, pp. 389-405. https://doi.org/10.1108/IJCHM-09-2017-0569

Wu, S.-H. and Gao, Y. (2019), "Understanding emotional customer experience and co-creation behaviours in luxury hotels", International Journal of Contemporary Hospitality Management, Vol. 31 No. 11, pp. 4247-4275. https://doi.org/10.1108/IJCHM-04-2018-0302

Altinay, L. and Taheri, B. (2019), "Emerging themes and theories in the sharing economy: a critical note for hospitality and tourism", International Journal of Contemporary Hospitality Management, Vol. 31 No. 1, pp. 180-193. https://doi.org/10.1108/IJCHM-02-2018-0171 


\section{INTERNATIONAL JOURNAL OF CONTEMPORARY HOSPITALITY MANAGEMENT}

Author Response Form

\begin{tabular}{|c|c|}
\hline & $\begin{array}{l}\text { Luo, J.(G)., Wong, I.A., King, B., Liu, M.T. and Huang, G. } \\
\text { (2019), "Co-creation and co-destruction of service quality } \\
\text { through customer-to-customer interactions: Why prior } \\
\text { experience matters", International Journal of } \\
\text { Contemporary Hospitality Management, Vol. } 31 \text { No. 3, pp. } \\
1309-1329 . \text { https://doi.org/10.1108/IJCHM-12-2017- } \\
0792 \\
\text { Shin, M., Back, K.-J., Lee, C.-K. and Lee, Y.-S. (2020), } \\
\text { "Enhancing customer-brand relationship by leveraging } \\
\text { loyalty program experiences that foster customer-brand } \\
\text { identification", International Journal of Contemporary } \\
\text { Hospitality Management, Vol. 32 No. 12, pp. 3991-4016. } \\
\text { https://doi.org/10.1108/IJCHM-06-2020-0550 }\end{array}$ \\
\hline $\begin{array}{l}\text { 5. Cross check all references within text with your } \\
\text { reference list and make sure that all references used in } \\
\text { within text are listed in your reference list and remove } \\
\text { any uncited reference from the reference list. You must } \\
\text { also make sure that each reference in your reference list } \\
\text { is accurate and complete in terms of authors' names, } \\
\text { title, volume number, issue number, pages, publisher etc. }\end{array}$ & $\begin{array}{l}\text { Thank you for your specific comments. } \\
\text { The references and citations have been carefully checked. } \\
\text { The format of references has been exactly followed the } \\
\text { requirement of the journal. }\end{array}$ \\
\hline $\begin{array}{l}\text { 6. Run your article through iThenticate, Crosscheck or } \\
\text { any similar software to check the similarity between your } \\
\text { study and previous studies. Try to minimize similarity } \\
\text { percentage below } 1 \% \text { with any previous study. }\end{array}$ & $\begin{array}{l}\text { Thank you for your kindly reminder. } \\
\text { The similarity has been checked by the website of } \\
\text { iThenticate. The similarity index is less than } 1 \% \text { from any } \\
\text { single sources. All of the contributions to the similarity } \\
\text { are random words (See the attached report). }\end{array}$ \\
\hline $\begin{array}{l}\text { 7. Keep your article below } 11000 \text { words including } \\
\text { references, tables and figures. }\end{array}$ & $\begin{array}{l}\text { Thank you for your specific comments. } \\
\text { By a carefully revision, words of the manuscript is } 10146 \\
\text { currently including references, tables and figures. }\end{array}$ \\
\hline 8. Make sure that the flow of your article is improved & $\begin{array}{l}\text { Thank you for your specific comments. } \\
\text { We have read through the entire manuscript and } \\
\text { improved the flow of the paragraphs. }\end{array}$ \\
\hline $\begin{array}{l}\text { 9. Proofread your article one more time and also you may } \\
\text { ask a technical writer/copy editor to proofread it for you. }\end{array}$ & $\begin{array}{l}\text { Thanks for your suggestion. } \\
\text { A proofreading has been conducted to enhance the } \\
\text { readability of this manuscript. }\end{array}$ \\
\hline $\begin{array}{l}\text { 10. Make sure you have all the co-authors, } \\
\text { acknowledgements, tables and figures included in your } \\
\text { submission. }\end{array}$ & $\begin{array}{l}\text { Thank you for your kindly reminder. } \\
\text { We have carefully examined the information of } \\
\text { authorships, acknowledgement, tables and figures to } \\
\text { ensure that nothing has been mistakenly omitted. }\end{array}$ \\
\hline
\end{tabular}

\section{ASSOCIATE EDITOR}

\begin{tabular}{l}
\hline Suggestions/comments from the associate editor \\
\hline 1. The theoretical foundation and theoretical implications \\
should be improved further. The following studies can \\
help the authors with this task. Below studies are just \\
suggestions and the authors may find similar relevant and \\
recent studies.
\end{tabular}

Response from the Author(s)

Thanks for your comments.

Most references that the associate editor recommended have relevance with our study. Therefore, 7 of 9 references have been incorporated into the manuscript. The below is the refences be included.

Ali, F., Park, E.(O)., Kwon, J. and Chae, B.(K). (2019), "30 years of contemporary hospitality management: Uncovering the bibliometrics and topical trends", International Journal of Contemporary Hospitality Management, Vol. 31 No. 7, pp. 2641-2665. https://doi.org/10.1108/IJCHM-10-2018-0832 


\section{INTERNATIONAL JOURNAL OF CONTEMPORARY HOSPITALITY MANAGEMENT}

Author Response Form

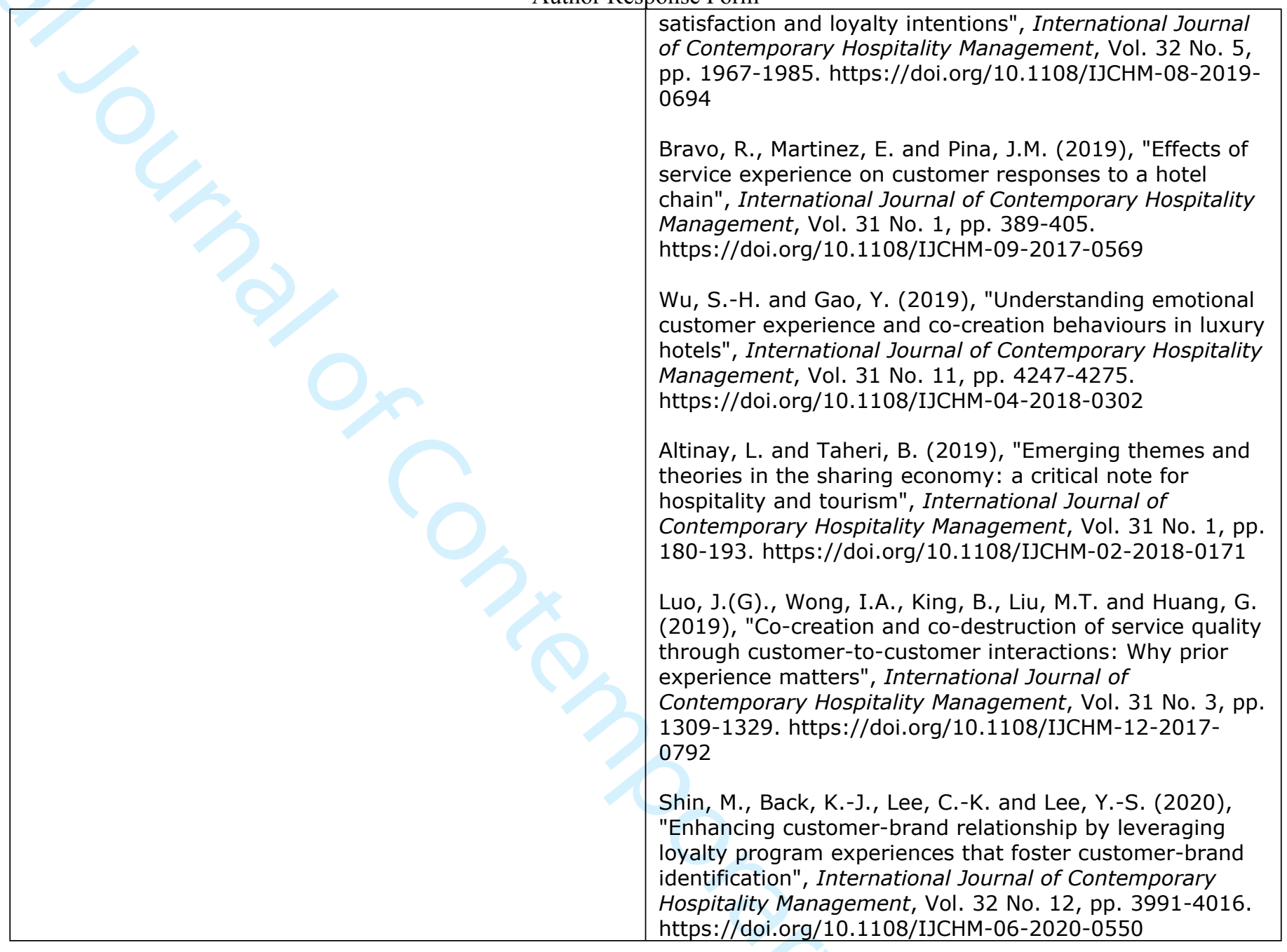

